\title{
Christoph Beck (1941-2017): a Chlamydomonas biologist
}

\author{
Michael Schroda ${ }^{1} \cdot$ Arthur Grossman $^{2}$
}

Published online: 18 September 2017

(c) Springer Science+Business Media B.V. 2017

Christoph Beck was born on March 4, 1941 in Wuppertal, Germany, and died on July 26, 2017 in Freiburg, Germany. He obtained his PhD at the University of California, Davis, in 1972, and habilitated at the University of Konstanz, Germany in 1979. Figure 1 shows a portrait of Christoph.

Christoph became a Professor of Genetics and Molecular Biology at the Albert-Ludwigs-University, Freiburg, in 1981, and remained there until 2006. He worked on bacterial tetracycline resistance till the end of the 1980s; his publications in this field are highly respected and cited (see e.g., Beck et al. 1982; Schneider and Beck 1986; Eckert and Beck 1989). During a visit to the laboratory of Don Weeks in Palo Alto, California, Christoph learned about the unicellular, green algal model organism Chlamydomonas reinhardtii (see: Rochaix et al. 1998). His excitement about exploiting this versatile organism for biological studies quickly converted him to a Chlamydomonas enthusiast and an ardent member of the Chlamydomonas community.

Christoph has authored or coauthored $\sim 100$ research publications. From his work on Chlamydomonas, we have gained important new insights into both sexual differentiation and the functions and mechanisms of photoperception

Invited, edited, and accepted on August 5, 2017, by Govindjee.

Michael Schroda

schroda@bio.uni-kl.de

Arthur Grossman

agrossman@carnegiescience.edu

1 Department of Molecular Biotechnology and Systems Biology, Technische Universität, 6733 Kaiserslautern, Germany

2 Department of Plant Biology, The Carnegie Institution for Science, Stanford, CA 94305, USA

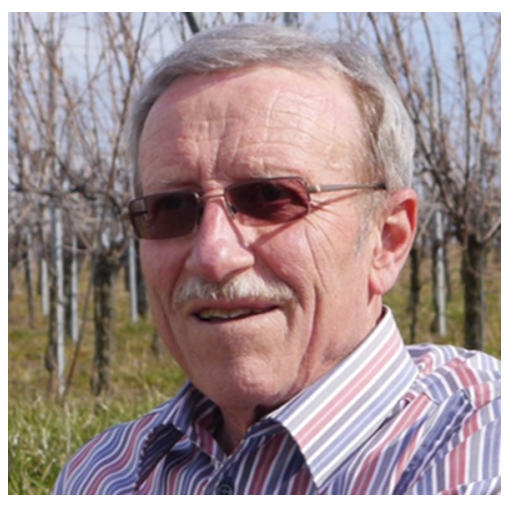

Fig. 1 A 2015 photograph of Christoph Beck. Source Astrid Beck

in algae (von Gromoff et al. 1989, 2008; Kropat et al. 1997; Schroda et al. 1999; Huang and Beck 2003).

Members of the Chlamydomonas community, numerous friends and his family will dearly miss him.

We thank Astrid, Christoph's wife, for the photograph and for her support.

\section{References}

Beck CF, Mutzel R, Barbe J, Muller W (1982) A multifunctional gene (tetR) controls Tn10-encoded tetracycline resistance. J Bacteriol 150:633-642

Eckert B, Beck CF (1989) Topology of the transposon Tn10-encoded tetracycline resistance protein within the inner membrane of Escherichia coli. J Biol Chem 264:11663-11670

Huang K, Beck CF (2003) Phototropin is the blue-light receptor that controls multiple steps in the sexual life cycle of the green alga Chlamydomonas reinhardtii. Proc Natl Acad Sci USA 100:6269-6274

Kropat J, Oster U, Rudiger W, Beck CF (1997) Chlorophyll precursors are signals of chloroplast origin involved in light 
induction of nuclear heat-shock genes. Proc Natl Acad Sci USA 94:14168-14172

Rochaix J-D, Goldschmidt-Clermont M, Merchant S (eds) (1998) The molecular biology of chloroplasts and mitochondria in Chlamydomonas. Advances in photosynthesis and respiration, vol 7. Springer, Dordrecht

Schneider K, Beck CF (1986) Promoter-probe vectors for the analysis of divergently arranged promoters. Gene 42:37-48

Schroda M, Vallon O, Wollman FA, Beck CF (1999) A chloroplasttargeted heat shock protein 70 (HSP70) contributes to the photoprotection and repair of photosystem II during and after photoinhibition. Plant Cell 11:1165-1178

von Gromoff ED, Treier U, Beck CF (1989) Three light-inducible heat shock genes of Chlamydomonas reinhardtii. Mol Cell Biol 9:3911-3918

von Gromoff ED, Alawady A, Meinecke L, Grimm B, Beck CF (2008) Heme, a plastid-derived regulator of nuclear gene expression in Chlamydomonas. Plant Cell 20:552-567 